\title{
НЕВЕРБАЛЬНІ ЗАСОБИ КОМУНІКАЦЇ: КОМПЛЕКСНА МЕТОДИКА ОПИСУ Й ЛЕКСИКОГРАФУВАННЯ
}

\author{
ТЕТЯНА ОСІПОВА \\ Харківський національний педагогічний університет імені Г. С. Сковороди, \\ Харків - Україна \\ ostaniya1967@gmail.com

\begin{abstract}
NIEWERBALNE ŚRODKI KOMUNIKACJI: KOMPLEKSOWA METODYKA OPISU I OPRACOWANIA LEKSYKOGRAFICZNEGO
\end{abstract}

TETIANA OSIPOWA

Charkowski Narodowy Uniwersytet Pedagogiczny imienia Hryhorija Skoworody, Charków - Ukraina

STRESZCZENIE. Artykuł poświęcono wybranym aspektom kompleksowej metodyki analizy niewerbalnych środków komunikacji we współczesnym dyskursie językoznawczym, czerpiącej z pragmatycznego podejścia do badania języka oraz polisensorycznej istoty komunikacji niewerbalnej.

\section{NON-VERBAL MEANS OF COMMUNICATION: NEW COMPLEX METHOD OF DESCRIPTION AND REGISTERING IN DICTIONARIES}

\author{
TETIANA OSIPOVA \\ H. S. Skovoroda Kharkiv National Pedagogical University, Kharkiv — Ukraine
}

ABSTRACT. The article represents the attempt to characterize some aspects of a complex methods of non-verbal means of communication analysis in a modern linguistic discourse, caused by a pragmatic approach to a language learning and a polysensored nature of a non-verbal communication.

$\mathrm{H}$

евербальна комунікація (НК) - одна 3 найбільш загадкових та суперечливих сутностей людської психіки, що впливає на формування певних моделей поведінки людини у спілкуванні та регулюється різноманітними чинниками комунікації загалом.

Полісенсорна природа НК репрезентує ,загальні, найбільш значущі види невербальної інформації (емоційну, естетичну, індивидуально-особистісну, біофизичну, соціально-типологічну, просторову, психологічну, медичну (...)", а тому аналіз ії виявів у міжособистісній комуникації має бути різноаспектним, що зумовлено, власне, метою комуникації - найбільш точного розкодування невербальної інформації й досягнення комунікативного взаєморозуміння.

Теоретичні основи НК, як відомо, закладені в 50-х роках XX ст. фахівцями американської та західноєвропейської антропології (М. Argail 1990; R. Birdwhistell 1970; P. Ekman 1999; J. Hall, M. Nepp 1972; F. Poyatos 1983; T. Sebeok

${ }^{1}$ В. П. Морозов, Невербальная коммуникация в системе речевого общения. Психофизиологические и психоакустические основы, [в:] Электронный ресурс: http://www.koob.ru/morozov_v_p/ (13.05.2017). 
1976), а на початку 80-х підхоплені й розвинуті російськими вченими, зокрема психологами (К. Абульханова-Славська 1986; О. Асмолов 1988; О. Бодальов 1982, 1996; А. Брушлинський, І. Горелов 1997; В. Знаков 1994; В. Лабунська 1986; О. Леонтьєв 1997; С. Рубінштейн 1976 та ін.) й лінгвістами (Т. Акішина 1999; Л. Златоустова, Р. Потапова, В. Трунін-Донський 1986; Г. Колшанський 1974; Г. Крейдлін, С. Григорьєва, Н. Григорьєв 2000 та ін.).

Безперечно, психологічний аспект є ключовим у вивченні НК, але його взаємодія 3 іншими антропологічними розробками значно розширює поле сучасних наукових інтенцій. Сучасна теорія дискурсу не лише створює підгрунтя міждисциплінарних зв'язків на прагматичному рівні, але й інтегрує „екстралінгвальні соціальні та референтні чинники (умови, час, простір комунікації), когнітивні й психологічні складники, що забезпечують взаємодію участників комуникації, їхні мотиви, цілі й стратегії”2 (перекл. з рос. автор. - Т. О.).

В Україні НК репрезентована переважно функціонально-семантичними дослідженнями в межах національної й міжкультурної дискурсивної практики (Т. Анохіна 2005; М. Гавриш 2012; А. Гнатюк 2014; Г. Демиденко 2014; Н. Киселюк 2009; Л. Козяревич 2006; Н. Коловоротна 2014; Т. Осіпова 2010; Л. Петровська 2006; Л. Солощук 2009 та ін.), однак відсутні грунтовні теоретичні розробки, хоча ще в 1975 р. набутком українського мовознавства стали роботи Л. Булаховського, присвячені питанням походження мови 3 актуалізацією невербального компонента, зокрема про хронологічне відношення мови жестів і словесної, мовний звуковий символізм, “порядокслів" умові жестів, фонетичне підтрунтя первісної мови, особливості мовлення дітей та ін.

Л. Булаховський актуалізував ряд проблем, пов'язаних зі з'ясуванням природи явища, указав на параметри невербальної, або паравербальної комунікації, зокрема іiі зв'язок з вербальною, особливості становлення й розвитку, лінгвістичний статус, типи й функції невербальных засобів тощо ${ }^{4}$.

Сьогодні в Україні є напрацювання, присвячені аспектуальному опису НК, зокрема такі, що репрезентують комунікативний ${ }^{5}$, психолінгвістичний ${ }^{6}$, соціолінгвістичний ${ }^{7}$, гендерний ${ }^{8}$, індивідуально-авторський ${ }^{9}$ і власне лінгвістичний ${ }^{10}$ аспекти. У зв'язку 3 цим виникає потреба укрупнення теоретичих

${ }^{2}$ О. Селів ван ова, Сучасна лінгвістика: термінологічна енциклопедія, Полтава-Київ 2006, с. 120.

3 Л.А.Булахо в ск и й, Избр. труды, в пяти томах, т. 1: Общее языкознание, Київ 1975.

${ }^{4}$ Т. Космеда, Т. Осіпова, Витоки теорії невербальної комунікації в украӥнському мовознавстві: актуалізація вчення Л. Булаховського, [в:] „Лінгвістичні дослідження”, зб. наук. пр. ХНПУ ім. Г. С. Сковороди, наук. ред. Л.А. Ли с и че н ко, Харків 2015, вип. 40.

${ }^{5}$ Т. Осіпова, Параметри вербальної і невербальної комунікаиії в украӥнських пареміях, дис. ... канд. філол. наук, Харків 2010.

${ }^{6}$ Н. К ис елюк, Вербальні та невербальні засоби актуалізаиї емоційного стану радості в художньому дискурсі (на матеріалі англомовної прози XX-XXI століть), дис... канд. філол. наук, Київ 2009.

${ }^{7}$ М. Га в р иш, Невербальна поведінка в ситуаціях сочіального і ситуативного домінування, [в:] Мова і суспільство, зб. наук праць, ред. Г. Мацюк, Львів 2010.

${ }^{8}$ T. Космеда, Т. Осіпова, Гендерно марковані комунікативні стратегї й тактики у вербальній і невербальній комунікачії, [в:] Гендерна лінгвістика в Украйні: історія, теоретичні засади, дискурсивна практика, наук. ред. Т. Ко см еда, Дрогобич 2014.

${ }_{9}^{9}$ Т. Космеда, Т. Осипов а, Индивидуально-авторское воспроизведение параметров невербальной коммуникачии в идиостиле писателя как элитарной языковой личности, [в:] Язык и культура в эпоху глобализации, сб. науч. трудов по матер. І межд. науч. конф. „Язык и культура в эпоху глобализации”, СПб. 2013, вып. 1, т. 2.

${ }_{10}$ T. Космеда, Т. Осіпова, Орнаментальна невербаліка в поетичному дискурсі С. Руданського, [в:] Степан Руданський: феномен моделювання ”живого“ мовлення украйнців, наук. ред. Т. Кос меда, Харків-Познань-Дрогобич 2015. 
постулатів НК з урахуванням сучасних напрацювань українських учених у сфері прагмалінгвістики, що й зумовлює актуальність цієї наукової розвідки.

Метою статті визначаємо спробу окреслити деякі аспекти комплексної методики аналізу невербальних засобів комунікації в сучасному мовознавчому дискурсі.

Прагмалінгвістичний підхід у вивченні мови змінив саму природу лінгвістичного аналізу, характер чинних методів, послідовність дослідницьких процедур. Комунікативна лінгвістика, вивчаючи процеси вербальної взаємодії, використовує інструментарій інших наук, зокрема психології, соціота культурології, семіотики, логіки тощо ${ }^{11}$. Таке аспектування поглиблює функціональну значущість мови і, виходячи із загальних постулатів аналітичної філософії, що передбачає аналіз мовних знаків як джерела визначення та розв'язання філософських проблем ${ }^{12}$, визначає мову як засіб загальної діяльності людини, забезпечуючи перехід від одного об'єкта дослідження до іншого - від людини й світу до мови, що надає можливість говорити про людину й світ ${ }^{13}$.

У філології, центральним об'єктом якої є мова й текст, уже чітко виформувалася тенденція до розгляду об'єктів не тільки в статиці, але й у динаміці, ставленні до мовця, пограничних та міждисциплінарних сфер іiї діяльності.

Загальновідомо, що вербальну та невербальну комунікації визначають як складники комунікативного процесу. Вербальну — як взаємодію між учасниками спілкування за допомогою мовного коду, а невербальну за допомогою паралінгвістичних засобів. Нерозривність цих складників у комунікативному процесі, можливість взаємних переходів, трансляцій, їх поєднання називають “подвійним кодуванням" 14 . Невербальні засоби комунікації репрезентуються в мовленні як відповідні коди, що потребують належного ступеня комунікативної компетенції для адекватного декодування інформації. Комунікативні смисли, утворені внаслідок “омовлення” невербаліки (“вербалізації невербаліки”) поглиблюють комунікативну й мовну компетенції учасників спілкування, розширюють мовний і комунікативний досвід. Саме комунікативна компетенція розмежовує лінгвістику й комунікацію, оскільки $\epsilon$ ключем декодування задуму мовця, вкладеного в повідомлення ${ }^{15}$. Зазначена дискурсивна методика знаходиться на шляху становлення й потребує відповідного термінологічного забезпечення, зокрема терміносполуки вербалізація невербаліки як базової.

Дискурсивний аналіз визначає особливості відтворення невербаліки в усному й писемному мовленні, зважаючи на синкретизм кодів вербальної й невербальної комунікації, зокрема універсальність, що “забезпечує доступність та зрозумілість кожному мовцеві, незалежно від його комунікативного досвіду спілкування” та дещо діаметральну етноспецифічність, що, навпаки, “звужує доступність невербального коду для комунікативних партнерів, які належать до інших лінгвоспільнот”. Індивідуальна означеність у структурі НК “вимагає

\footnotetext{
${ }^{11}$ М. Ю. Олеш шов, Моделирование коммуникативного процесса, Нижний Тагил 2006.

${ }^{12}$ См.: М. А. Кронгауз, Семантика, Москва 2001.

${ }^{13}$ М. Ю. Олешко в, зазнач. джер., с. 10-16.

${ }_{14}$ Т. Ф. Осіпова, Параметри вербальної і невербальної комунікачії в украйнських паремiях..., с. 43.

${ }^{15}$ Т. Ф. О с іп о в а, Вербалізаиія “невербалики”: інновачійні словотвірні тендениї в системі мовознавчої термінологї, [в:] Лексико-грамматические инновации в современных славянских языках, матер. VI Межд. научн. конф., под ред. Т. С.При с тай ко, Днепропетровск 2013.
} 
додаткових знань про співрозмовника для адекватного декодування" ${ }^{16}$. Аналіз художнього мовлення Т. Шевченка, С. Руданського, І. Франка ${ }^{17}$ ілюструє зазначені вище постулати щодо омовлених у художніх текстах параметрів НК, що утворюють своєрідну систему мовних засобів, які містять мовно-культурний код нащіï. Наприклад, мова поетичних творів С. Руданського знайомить нас із його власною комунікативною компетенцію щодо репрезентації параметрів невербаліки, зокрема форазеологізмами, при цьому співомовки потенційно характеризують і мовну особистість українця загалом ${ }^{18}$.

У тексті невербальні засоби комунікації можуть репрезентуватися як експліцитним, так й імплічиттним способами, що вимагає від адресата певних прецедентних знань або досвіду, зокрема для розкодування найбільш значущих рухів, порівн.: „Спасибі вам!” - Надів шапку (Т. Шевченко, Іван Підкова) рух на позначення завершення розмови або спільної справи; Подай же руку козакові / I серие чистеє подай! / I знову іменем Христовим / Ми оновим нам тихий рай (Т. Шевченко, Полякам) - імператив, що спрямовує комунікацію в напрямку розвитку, поступу. При цьому імпліцитність параметрів НК може виявлятися як на культурологічному, так і на когнітивному рівні - мовна спроможність індивіда є функційною системою, „компоненти якої «працюють» за специфічними правилами, за якими й здійснюється вибір засобів, що необхідні для вирішення кожного конкретного комунікативного завдання, наголошуючи при цьому на наявності семантичного компонента - підсистеми правил вибору адекватного значення для реалізації відповідного смислу" 19 , порівн.: Нехай мати усміхнеться, Заплакана мати. Благословить дітей своїх / Твердими руками / I діточок поцілує / Вольними устами (Т. Шевченко, I мертвим, $i$ живим, $i$ ненародженим...) - ритуальне значення руху хрещення на знак благословення репрезентовано прецедентним текстом, що передбачає певний рівень компетентності адресата (читача або слухача).

Винятково контекстуально можливим видається виявити жанрову синкретичність деяких рухів, порівн.: "Ой панночки-голубчики, Єй-богу, немає!" “Брешеш, шельмо!” [...] "Перехрестись!” - хреститися на знак переконання, клятви; Подумавши, перехрестивсь Та й знов пішов у наймити... (Т. Шевченко, Москалева криниия) - використання руху хрещення як оберегу перед небезпечною або складною справою.

${ }^{16}$ Л. В. Солощук, Взаємодія вербальних і невербальних компонентів комунікаиії у сучасному англомовному дискурсі, автореф. дис. ... д-ра філол. наук, Київ 2009.

${ }^{17}$ Т. Ф. Осіпова, Вербалізація паралінгвальних засобів комунікації у творах Т. Г. Шевченка, [в:] „Лінгвістичні дослідження”, зб. наук. праць ХНПУ ім. Г. С. Сковороди, наук. ред. Л. А. Лисиченко, Харків 2013; Т. Ф. Осіпова, Невербальні параметри комунікаиії як мовно-культурний код нації і складова портрету мовної особистості (на матеріалі „, Співомовок”, C. Руданського), [в:] „Наук. записки Тернопіл. нац. пед. ун-ту ім. В. Гнатюка. Сер. Мовознавство”, зб. наук. пр., наук. ред. Т. П. Вільчин ська, Тернопіль 2014, вип. 2 (24); Т. Ф. Осіпова, Репрезентація параметрів невербальної комунікації у творах Михайла Коцюбинського, [в:] „Studia Ukrainica Posnaniensia”, red. nauk. T. Kosmeda, Poznań 2015, zeszyt III; T. Ф. Осіпов в, Національна невербаліка в поетичному мовленні Степана Руданського, [в:] „Studia Ukrainica Posnaniensia", red. nauk. T. Kosme da, Poznań 2015, zeszyt IV; T. Ф. Ос іп о ва, Орнаментальна невербаліка в поетичному дискурсі С. Руданського, [в:] „Український світ у наукових парадигмах”, зб. наук. праць Харків. нац. пед. ун-ту ім. Г. С. Сковороди, наук. ред. О. О. Маленко, Харків 2016, вип. 3 та ін.

${ }^{18}$ Див. про це: Т. Космеда, Т. Осіпова, Н. Піддубна, Степан Руданський: феномен моделювання “живого” мовлення українців, наук. ред. Т. Космеда, Харків-Познань-Дрогобич 2015.

19 T. А. Космеда, Ego i Alter Ego Tapaca Шевченка в комунікативному просторі щоденникового дискурсу, Дрогобич 2012, с. 20. 
Невербальні засоби комунікачії:

комплексна методика опису й лексикографування

Вербалізація комунікативних ситуацій, способів “уплетення" в поетичне мовлення вербальних і невербальних параметрів зумовлює утворення різних типів контекстів, серед яких науковці виокремлюють дублювальний (невербальний компонент повторює зміст вербального повідомлення), протиставний (значення невербального компонента протиставляється змісту вербального повідомлення), замісний (так званий “німий діалог”, коли жест повністю заміщує словесне повідомлення або невербаліка в діалозі заміщує окремі репліки; найчастіше цей контекст репрезентований етикетними та дейктичними (оцінними) жестами), доповнювальний (об'єднує невербальний компонент 3 вербальним, коли невербальний складник комунікації поширює або модифікує зміст висловлювання), уточнювальний (невербальний компонент конкретизує зміст окремої частини висловлювання) ${ }^{20}$.

Аналіз контекстів 3 невербальним компонентом надає можливість виокремити три способи їхньої репрезентації: 1) експлікація форми; 2) експлікація значення; 3) експлікація форми й значення водночас ${ }^{21}$. На жаль, сьогодні цей методичний аспект ще не апробований на українському дискурсивному матеріалі.

Одним зі значущих складників емоції вважають експресивний компонент, що репрезентує виразні рухи - міміку, жести, пантоміміку, голосові реакції невербальні засоби. Наявність цього компоненту в невербаліці відзначав Ч. Дарвін, наголошуючи на пристосувальній ролі виразних рухів, що супроводжують емоцію. „Емотивна компетенція мовної особистості виявляється і в її вмінні породжувати в практиці комунікації емотивно коректні тексти"22. На сьогодні розроблено й самостійний напрям мовознавства - лінгвоемоціологію (див. праці російського дослідника В. Шаховського чи української дослідниці В. Сліпецької) 23 , у межах якого, як видається, також необхідно вивчати систему невербальних і паравербальних засобів, що дають змогу описувати емоційність, вербалізувати почуття, хоч цей дослідницький аспект лінгвоемоціологія, на жаль, не враховує ${ }^{24}$.

Вербалізацію невербальних стратегій і тактик найпростіше простежити на прикладах фразеологізмів відповідного змісту, пов'язаних, напр., 3 візуальним контактом, порівн.: стріляти очима; аж іскри з очей сипляться; оком (очима) накинути; очі горять; очей не відведеш; вбирати очима тощо. Контекстуальний аналіз надає можливість виявляти апостеріорні смисли, тобто

20 См.: А. Е. Зуева, Вербализачия паралингвистических актов в художественном тексте современной немеикой литературы, автореф. дис. ... канд. филол. наук, Белгород 2005.

${ }^{21}$ Там же, с. 8.

${ }_{22}^{22}$ Т. А. Космеда, Ego i Alter Ego ..., с. 54.

23 Див., напр.: В. И. Шаховский, Лингвистическая теория эмоиий, Москва 2008; В. Д. С лі іп ец к а, Засоби вираження негативної оиінки та негативних емоиій в украйнській та російській лінгвокультурах (на матеріалі повісті М. Гоголя „Вечори на хуторі біля Диканьки”), [в:] „Лінгвістичні дослідження”, зб. наук. праць ХНПУ ім. Г. С. Сковороди, наук. ред. Л.А.Л ис ич ен ко, Харків 2012, вип. 34; В.Д.С ліп е ь ка, Вербалізація негативних емоцій: тенденції формування нового мовленнєвого стандарту, [в:] „Наук. вісн. Дрогоб. держ. пед. ун-ту ім. Івана Франка. Сер. Філологічні науки. Мовознавство”, зб. наук. праць, наук. ред. О. А. Бабелюк, Дрогобич 2015, № 3; В . Д. С лі іп е ц ь ка, Гнів як причина з'яви конфліктної ситуації в комунікації (на матеріалі паремій украӥнської, російської, англійської мов), [в:] „Вісн. Запор. нац. ун-ту”, 3б. наук. праць, наук. ред. В. М. Манакін, Запоріжжя 2012, вип. 53; В. Д. Сліпецька, Негатив у комунікації: маніпулятивні стратегї̈ і тактики конфліктного спілкування, [в:] „Вісн. Житомир. держ. ун-ту ім. І. Франка”, наук. ред. П. Ю. С ау х, Житомир 2012, вип. 62 та ін.

${ }^{24}$ T. Космеда, Т. Осіпова, Н. Піддубна, Степан Руданський..., с. 232. 
такі смисли, що народжуються в процесі спілкування, порівн.: Стояла Мотря $\breve{u}$, граючи очима, ласкаво всміхалася (В. Винниченко); грати очима - 'грайливо поглядати на когось, прагнучи звернути на себе увагу, викликати до себе інтерес' - репрезентує емоції задоволення, радості, захвату, замилування, симпатії, ніжності тощо.

Дослідження та опис метамови невербаліки є одним зі шляхів поглиблення знань про найбільш значущі паралінгвальні засоби комунікації.

Як зазначають фахівці, у межах метамовної рефлексії як „усвідомленого використання мови 3 метою аналізу різноманітних фактів"25 доцільно розглядати судження про кожний компонент мовної ситуації: "використаний код (вербальні та невербальні засоби), інтенції мовця та адекватність їхнього мовленнсвого втілення, релевантних ситуації характеристики адресанта й адресата повідомлення, умови комунікації тощо"26.

Нанизування й перетинання методичних аспектів аналізу вербалізації паралінгвальних засобів у процесі описування комунікативної поведінки надає можливість діагностувати внутрішній стан, приховані думки, ставлення до світу і т. ін., що виражає сутність знакового опосередкування свідомості людини.

Наявний теоретично-описовий доробок потребує певних узагальнень, систематизації й кодифікації, а також лексикографічної фіксації. Слов'янський лексикографічний досвід у цьому напрямку презентує словник Жесты и мимика в русской речи А. Акішиної та ін. ${ }^{27}$ (1991), до перших практик лексикографічного опису жестів, в основі якого принципи інтегральної інтерпретації, належить Словарь языка русских жестов Н. Григор'єва, С. Григор'євої, Г. Крейдліна ${ }^{28}$ (2001). Світовий досвід невербального словникарства передусім спрямований на практику використання жестів у повсякденному житті й опанування рідної та іноземної мов, серед яких - одна з останніх лексикографічних праць французького психолога Жозефа Мессинжера ${ }^{29}$ (2015), що становить оригінальне видання енциклопедичного змісту науково-популярного характеру і має базовий потенціал для створення інших сучасних словників невербаліки.

Розробляючи теорію лексикографії, Л. Щерба наголошував, що „словникова робота заснована винятково на семантиці, а отже, вимагає особливо тонкого сприйняття мови й такого обдарування, яке, імовірно, $є$ родинно письменницьким даром" "30

В Україні, на жаль, на сьогодні немає словників, що ілюстрували б національно-культурну специфіку невербальної комунікації, хоч мають місце певні фрагментарні розробки. Актуальними є дослідження процесів вербалізації невербаліки в аспектах молодих наукових дисциплін - лінгвокультурології ${ }^{31}$,

${ }^{25}$ Т. В. Шмелева, Языковая рефлексия, [в:] Теоретические и прикладные аспекты речевого общения, Красноярск 1999, вып. 1 (8).

${ }^{26}$ М. Р. Шумарина, Метаречевые наблюдения писателей на занятиях по риторике и культуре речи, [в:] Проблемы современного коммуникативного образования в вузе и школе, матер. II Всерос. науч.-практ. конфер. с междунар. участием, в 2-х ч., Новокузнецк 2009, ч. 1.

${ }^{27}$ А. А. Акишина и др., Жесты и мимика в русской речи, Москва 1991.

${ }^{28}$ С. А. Григорьева, Н. В. Григорьев, Г. Е. Крейдлин, Словарь языка русских жестов, Москва-Вена 2001.

${ }^{29}$ Ж. Мес синже р, Словарь жестов, пер. с фр. А. Дадык и на, Москва 2015.

30 Л. В. Щерба, Опыт общей теории лексикографии, Ленинград 1958, с. 76.

${ }^{31}$ Т. А. Космеда, Н. А. Карпенко, Т. Ф. Осіпова, Л. М. Саліонович, О. В. Халіман, Гендерна лінгвістика в Україні: історія, теоретичні засади, дискурсивна практика, наук. ред. Т. Космеда, Харків-Дрогобич 2014. 
Невербальні засоби комунікачії:

комплексна методика опису й лексикографування

лінгвоперсонології ${ }^{32} 33$, гендерології ${ }^{34}$, комунікативістики ${ }^{35}$. Такий практичний доробок сприяв би видовому урізноманітненню невербальної лексикографії у вигляді фразеологічних, лінгвокультуологічних, індивідуально-стильових, гендерних словників $з$ невербаліки, комунікативних словників активного типу та ін. Розробка нових ідей, методик і концепцій дослідження невербальної комунікації становить перспективу цієї проблематики в Україні і світі загалом.

${ }^{32}$ T. Космеда, Т. Осіпова, Н. Піддубна, Степан Руданський...

${ }^{33}$ А. Горн я тко-Шумилович, Т. Космеда, Феномен креативності Василя Симоненка: літературознавчий та лінгвістичний аспекти, наук. ред. Т. Космеда, Познань 2016.

34 T. А. Космеда. Н. А. Карпенко, Т. Ф. Осіпова, Л. М. Саліонович, О. В. Халіман, зазнач. джер.

${ }^{35}$ Т. А. Космеда, Т. Ф. Осіпова, Комунікативний кодекс українців у пареміях: тлумачний словник нового типу, Дрогобич 2010. 